\title{
The Influence of Economic Growth, Number of Students in Vocational Secondary School and Unemployment Rate to Poverty Rate in North Sumatera Province
}

\author{
Patryano G. Anggara \\ Graduate Program of Economics \\ Universitas Negeri Medan \\ North Sumatra \\ Petrickgabe@yahoo.co.id \\ M. Fitri Rahmadana \\ Graduate Program of Economics \\ Universitas Negeri Medan \\ North Sumatra \\ mufitra_140977@yahoo.co.id \\ Indra Maipita \\ Graduate Program of Economics \\ Universitas Negeri Medan \\ North Sumatra \\ imaipita@gmail.com
}

\begin{abstract}
Economic growth, unemployment rate and the number of students in vocational schools have an important role in influencing poverty alleviation in North Sumatra Province. This study aims to determine the effect of economic growth, unemployment rate and the number of students of vocational secondary school (VSS) to poverty level in North Sumatra Province from 2001 to 2015. The data used are secondary data obtained from Central Bureau of Statistics (BPS) of North Sumatra Province. The analysis technique used is multiple regression analysis. The study concludes that economic growth, unemployment rates and the number of students in vocational schools have significant impact on poverty levels in the province of North Sumatra. The existence of a significant influence between economic growth, unemployment rate, and the number of students at VSS level against poverty level indicates that Provincial Governments need to implement policies in an effort to increase economic growth, unemployment rate. and the number of students in vocational schools to stimulate poverty alleviation in North Sumatra Province, so that the level of poverty can be controlled.
\end{abstract}

Keywords - Economic Growth, Number of Students, Unemployment Rate, and Poverty Rate

\section{INTRODUCTION}

The expected increase in economic growth is not only a measure of a country's economic success but also as a way to address development problems such as poverty, income and unemployment [1odaro]. Increased economic growth can indicate a lot of investment made by the Government.

Especially in the improvement of human resources (HR). Education is one investment in the field of human resources. The indicator of the success of investment in the world of education is to create skilled human beings [5].

In order to achieve success indicators, one way through vocational secondary school (vss). With vss, the government of Indonesia not only achieves such an indicator, it is also capable of overcoming unemployment problems through the provision of skills tailored to student potential. This will instantly make the workforce more skilled so that it will reduce the unemployment rate. This is because the unemployment rate in Indonesia is mostly unskilled labor that is not absorbed by the company. Thus, the more students in vss will contribute to the workforce to be absorbed. So indirectly will result in the number of unemployment is reduced and tend to reduce the level of poverty.

But in fact, the increase in economic growth in developing countries is only pseudo and not always followed by 
improving the quality of education, especially vss. So it still produces a number of high unemployment.

If the number of unemployment is high, then many people do not have the income to meet their needs, thus reducing their needs [8]. Poverty is usually described as the low income owned by a person to meet the basic requirement. The inability of a person to meet his needs because it does not have sufficient income will result in him being on the poverty line.

\section{TABLE I}

Percentage of economic growth, the number of students in the vocational school, the unemployment rate and poverty rate in North Sumatra province in the year 2001 to 2016

\begin{tabular}{|c|c|c|c|c|}
\hline Years & $\begin{array}{c}\text { Economic } \\
\text { Growth }\end{array}$ & $\begin{array}{c}\text { The } \\
\text { Number } \\
\text { of } \\
\text { Students }\end{array}$ & $\begin{array}{c}\text { The } \\
\text { Unemployment } \\
\text { Rate }\end{array}$ & $\begin{array}{c}\text { The } \\
\text { Poverty } \\
\text { Rate }\end{array}$ \\
\hline 2001 & 3.72 & 200.510 & 9.09 & 15.94 \\
\hline 2002 & 4.07 & 205.558 & 10.30 & 15.84 \\
\hline 2003 & 4.42 & 192.796 & 11.02 & 15.89 \\
\hline 2004 & 5.74 & 194.180 & 13.75 & 14.93 \\
\hline 2005 & 5.48 & 178.294 & 10.98 & 14.68 \\
\hline 2006 & 6.20 & 170.418 & 11.51 & 15.66 \\
\hline 2007 & 6.90 & 202.310 & 10.1 & 13.9 \\
\hline 2008 & 6.39 & 249.649 & 9.1 & 12.47 \\
\hline 2009 & 5.07 & 249.649 & 8.45 & 11.27 \\
\hline 2010 & 6.42 & 152.653 & 7.43 & 11.36 \\
\hline 2011 & 6.63 & 152.653 & 6.37 & 10.83 \\
\hline 2012 & 6.45 & 257.795 & 6.2 & 10.41 \\
\hline 2013 & 6.08 & 257.795 & 6.53 & 10.39 \\
\hline 2014 & 5.23 & 257.682 & 6.23 & 9.85 \\
\hline 2015 & 5.10 & 278.820 & 6.71 & 10.53 \\
\hline 2016 & 5.18 & 274.334 & 5.84 & 10.35 \\
\hline & & \multicolumn{2}{|c|}{ Data source: BPS province of North Sumatra } \\
\hline
\end{tabular}

Based on the above table, the highest level of poverty in North Sumatra is in 2001 that is $15.94 \%$, where economic growth is still low at $3.72 \%$ but the number of vocational students is quite high at 200,510, and also the high unemployment rate of $9,09 \%$.

Economic growth of North Sumatra Province was the highest in 2007 of $6.90 \%$, but the increase was accompanied by an increase in the number of students in VSS from 170.418 to 202,310 , and the decrease in unemployment rate by $11.51 \%$ to $10.1 \%$, poverty also experienced decrease from $15,66 \%$ to $13.9 \%$. However, in 2014, the province of North Sumatra experienced a sharp decline in economic growth from $6.08 \%$ to $5.23 \%$, but the decline was accompanied by a decrease in the number of students in vss from 257,795 to 257,682 and followed by a decrease in unemployment from $6.53 \%$ to $6.23 \%$, thus affecting the poverty rate which also decreased from $10.39 \%$ to $9.85 \%$. This is not in accordance with the opinion of Perry et.al that: "economic growth has an important role in poverty alleviation, where the benefits of economic growth will rapidly spread across the segments of society". This opinion is based on the Trickle Down Effect theory [6].
Where the theory of Trickle Down Effect mentions the existence of the flow from the rich to the poor through functions in the economy. Based on the phenomenon, the author is interested to conduct research that aims to determine whether economic growth, the number of students in VSS, and unemployment rate affect the level of poverty in the Province of North Sumatra. So that the results of this study can be recommended to the provincial government in poverty alleviation in the Province of North Sumatra.

\section{LITERATURE REVIEW}

According to Kuznet's theory, economic growth is a longterm capacity-building of a country in meeting the economic goods of its population [10]. The increase is determined by the increase of production factor. The addition of factors of production is not always followed by an increase in the production of goods and services of the same magnitude. The potential increase in production is usually greater than the actual increase in production. So that will lead to economic development becomes slower than its potential. [9]. Therefore, it is necessary to improve the quality of human resources in order to increase the capacity of the country. Improving the quality of human resources is an effort to improve human quality with the development of activities in the field of education and training. Vss is one of the means in improving the ability of knowledge and skills through the training provided.

Vocational education is one of human resources, called human capital (human capital theory). Educational investment at the vss level is an activity that can increase humanitarian value, where humanitarian value will increase after attending vss's education and training. One of the successes of this increase can be seen from the increasing number of students in vocational schools. The more students in the vss, the more people will experience improvement in the level of life. Increased living standards can increase the level of individual income, increase work productivity, and increase the rational value (social benefits) of individuals [5]. Rising standards of living will have a negative impact on unemployment. Where more and more students are in the vss, the lower the unemployment rate.

But in fact, the unemployment rate in North Sumatra Province is still high. According to Suparmoko (2007) unemployment is "the inability of the workforce to get jobs as they expect". The high unemployment rate will lead to increased poverty rates. Poverty is usually understood as a state in which a human cannot guarantee its survival. According to BPS [4]. Poverty is seen as the inability of humans to meet the basic needs of food and not food as measured by the expenditure side. According to Ravallion [3]. poverty is "starving, homeless, lack of funds for treatment".

According Arsyad, "poverty is caused by two factors, among others: natural or cultural factors and factors that are non-natural or structural" [3]. According to Paul Spicker (Wijayanto, 2010) the causes of poverty can be divided into four madzab, namely individual explanation, familial explanation, subcultural explanation, structural explanation. 
There are three groups of people considered poor by Sajogya (1997), the poor, the very poor, and the poor [3]. The poor will consume per-capita rice as much as $320 \mathrm{~kg}$ per year for rural areas whereas for urban areas of $480 \mathrm{~kg}$ per capita in one year, the very poor will consume per-capita rice as much as $240 \mathrm{~kg}$ per year in rural and $360 \mathrm{~kg}$ in urban areas, and the impoverished group consume per capita rice of $180 \mathrm{~kg}$ per year in rural and 270 in urban areas. However, in 1997 the poor category was converted into a near-poor category where rice consumption per capita was $480 \mathrm{~kg}$ in rural and $720 \mathrm{~kg}$ in urban areas per year.

As for previous research which becomes reference writers in compiling this research, among other things:

Ady Soejoto and Ameilia Karisma, "Economic growth and unemployment Against poverty in East Java," where the results of his research concluded that the influence of economic growth has a negative effect against poverty, where economic growth is increasing then the poverty levels will decrease, while the unemployment rate has a positive effect against poverty levels, where the higher level of unemployment, it will be the higher levels of poverty.

Yarlina Yacoub, "The effect of unemployment rate Against poverty level Kabupaten/Kota In West Kalimantan province" where the results of a research that effect the unemployment rate significantly to poverty levels in West Kalimantan province. Although, empirical data show a pattern of relationships which are not always aligned between the unemployment rate and the level of poverty.

Radityo Yudi Wibisono "The analysis of the influence on Gdp, unemployment and education Against poverty in Central Java the year 2008 - 2013", where his research results showed that the GDP variable has a negative influence significantly to poverty. While the unemployment variable indicates the existence of a positive and significant relationship against poverty. However, the level of education does not have a significant impact against poverty.

\section{RESEARCH METHODS}

Source of data on research is secondary data, obtained from North Sumatra Province BPS year-2001-2016. As for the research methods used in this research is to use multiple linear regression model approach that serves to know the influence of variable factor of economic growth, the number of students in the vocational school, as well as the unemployment effect against poverty in 2001-2016 in the province of North Sumatra.

Referring to the basic theory and previous research, then the research hypothesis can be taken as follows:

$\mathrm{H}_{1}$ : Economic growth, the number of students in the vocational school, and unemployment levels have an impact on poverty levels in the province of North Sumatra.

$\mathrm{H}_{0}$ : Economic growth, the number of students in the vocational school, and the unemployment rate has no effect on the level of poverty in the province of North Sumatra.
Based on the research hypothesis, the research design can be described and made the regression equation as follows:

\section{PICTURE I}

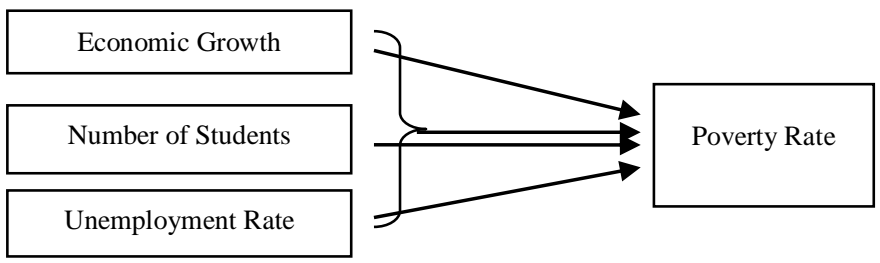

Based on data observation and simulation of regression result, it is decided the equation model used is:

$$
\mathrm{Y}=\mathrm{a}+\mathrm{b} 1 \mathrm{X} 1+\mathrm{b} 2 \mathrm{X} 2+\mathrm{b} 3 \mathrm{X} 3+\mathrm{ei}
$$

$$
\begin{array}{ll}
\multicolumn{1}{c}{\text { Description : }} & \\
\mathrm{Y} & =\text { Poverty Rate } \\
\mathrm{X} 1 & =\text { Economic Growth } \\
\mathrm{X} 2 & =\text { Number of students in VSS } \\
\mathrm{X} 3 & =\text { Unemployment Rate } \\
\mathrm{a} & =\text { Constants } \\
\mathrm{b} 1, \mathrm{~b} 2, \mathrm{~b} 3 & =\text { Regression coefficient } \\
\mathrm{ei} & =\text { Disorder factor }
\end{array}
$$$$
\text { Y }
$$

\section{RESULTS AND DISCUSSION}

\section{TABLE II}

Results of Multiple Linear Regression Analysis

Model Summary

\begin{tabular}{|c|r|r|r|c|}
\hline Model & $\mathrm{R}$ & $\mathrm{R}$ Square & $\begin{array}{c}\text { Adjusted R } \\
\text { Square }\end{array}$ & $\begin{array}{c}\text { Std. Error of the } \\
\text { Estimate }\end{array}$ \\
\hline 1 & $.941^{\mathrm{a}}$ & .885 & .856 & .90645 \\
\hline
\end{tabular}

From the result of data processing through SPSS 20 media by using multiple linear regression model, $\mathrm{R}^{\mathbf{2}}=0,885$, meaning that $88,5 \%$ percentage of poverty level can be explained by economic growth variable, number of students in VSS and unemployment rate in North Sumatera and $11.5 \%$ is influenced by other variables not included in this study. The impact of economic growth, the number of students in VSS, and the unemployment rate on poverty levels are also consistent with the trickle-down effect theory, where increased economic growth will lead to a positive impact on poverty.

The higher the rate of economic growth, the lower the poverty rate. The results of this research regression are not in accordance with the research of Radityo Yudi Wibisono (2013) which summarizes the influence of pdrb, Unemployment, but the education of vaiabel has no effect on Poverty in Central Java in 2008-2013. 
TABLE III

Results of Result T-Test

Coefficients $^{\mathrm{a}}$

\begin{tabular}{|c|c|c|c|c|c|c|}
\hline \multirow{2}{*}{\multicolumn{2}{|c|}{ Model }} & \multicolumn{2}{|c|}{$\begin{array}{l}\text { Unstandardized } \\
\text { Coefficients }\end{array}$} & $\begin{array}{c}\text { Standardized } \\
\text { Coefficients }\end{array}$ & \multirow[t]{2}{*}{$\mathrm{t}$} & \multirow[t]{2}{*}{ Sig. } \\
\hline & & B & $\begin{array}{l}\text { Std. } \\
\text { Error }\end{array}$ & Beta & & \\
\hline \multirow{4}{*}{1} & (Constant) & 14.736 & 2.943 & & 5.007 & .000 \\
\hline & Economic Growth & -.855 & .259 & -.339 & -3.302 & .006 \\
\hline & $\begin{array}{c}\text { Number of Students } \\
\text { in VSS }\end{array}$ & $\begin{array}{r}-1.486 \mathrm{E}- \\
005\end{array}$ & .000 & -.268 & -2.277 & .042 \\
\hline & $\begin{array}{c}\text { Unemployment } \\
\text { Rate }\end{array}$ & .690 & .118 & .687 & 5.848 & .000 \\
\hline
\end{tabular}

a. Dependent Variable: Poverty Rate

Based on the results of the t-test, it is obtained:

- The value of $\mathrm{t}$ test for economic growth variable is 3.302. This means that economic growth has a negative and significant impact on poverty levels in North Sumatra Province, where if there is an increase in economic growth, it will affect the decline of poverty level in North Sumatra province. This result is in accordance with the research of Ady Soejoto and Ameilia Karisma (2011) which shows that the level of economic growth negatively affect the level of poverty in East Java Province.

- The value of $t$ test for the student number variable in Smk is -2.277 . This means that the number of students in Smk has a negative and significant influence on poverty level in North Sumatra Province, where if there is an increase in the number of students In VSS, it will affect the decline in poverty level in North Sumatra province. The number of students in VSS will reflect that the North Sumatra Provincial Government is committed to investing in education. This is not in accordance with Durrotul Mahsunah's research, where the results of his research show there is no influence between education and poverty in East Java.

- The value of $t$ test for the unemployment rate variable is 5,848. This means the unemployment rate has a positive and significant effect on poverty level in North Sumatera Province, so if there is an increase in unemployment rate, it will automatically increase poverty level in North Sumatera province. This result is in accordance with Asyad's (2010) opinion that the unemployment rate has a very close relationship with high poverty and uneven income.
TABLE IV

Results of Result F-Test

\begin{tabular}{|c|c|c|c|c|c|c|}
\hline \multicolumn{7}{|c|}{ ANOVA $^{a}$} \\
\hline & Model & $\begin{array}{c}\text { Sum of } \\
\text { Squares }\end{array}$ & $\mathrm{df}$ & Mean Square & $\mathrm{F}$ & Sig. \\
\hline \multirow{3}{*}{1} & Regression & 76.017 & 3 & 25.339 & 30.839 & $.000^{\mathrm{b}}$ \\
\hline & Residual & 9.860 & 12 & .822 & & \\
\hline & Total & 85.877 & 15 & & & \\
\hline
\end{tabular}

Based on the above table, then get the value of $\mathrm{F}$ equal to 30,839 with significance 0,000 . So it can be concluded that $\mathrm{H} 1$ accepted, where economic growth, the number of students in VSS, and unemployment rate simultaneously have a significant effect on Poverty Level in North Sumatra Province. This result is not in accordance with research conducted by Radityo Yudi Wibisono, entitled "Influence Analysis of Pdrb, Unemployment and Education on Poverty in Central Java Year 2008 -2013" where the results showed that the variable of GRDP has a significant negative effect on poverty While the unemployment variable shows a positive and significant relationship to poverty. However, the level of education has no significant impact on poverty. Despite having the result equation with the GRDP variable and the Unemployment rate, but for educational outcomes, this study is inconsistent with current research.

\section{CONCLUSIONS AND SUGGESTIONS}

\section{A. CONCLUSIONS}

Based on multiple regression analysis on Economic Growth, Number of Students in Smk and Unemployment Rate on Poverty Level in North Sumatera Province. Then the following conclusions can be drawn :

1. Test results show growth rates. Where the higher economic growth, it will further reduce the level of poverty in the Province of North Sumatra.

2. The test results show that the number of students in VSS has a negative and significant influence on the poverty level. Where the higher the number of students in VSS, it will further reduce the level of poverty in the Province of North Sumatra.

3. The test results show that the Adjustment Rate has a positive and significant influence on the poverty level. Where the higher the unemployment rate, it will further increase the level of poverty in the Province of North Sumatra.

\section{B. SUGGESTIONS}

Based on this research, the authors can provide some suggestions related to the results of research as a material to be used as input and consideration that can be useful for the 
parties related, especially the government of North Sumatra Province, among others:

1. With the increase in economic growth created, the North Sumatra provincial government should be able to create a number of jobs that are able to absorb unemployment, so that will affect the decline in poverty levels in the province of North Sumatra.

2. The government should improve the quality of education in vocational schools to increase the number of students, so the goal of having skilled workforce and character achieved, so that ultimately will reduce unemployment that led to the reduction of poverty.

3. North Sumatra Provincial Government should conduct entrepreneurship training to the community, so that with the training received by the community can be more daring to open new jobs and not just looking for work.

\section{REFERENCES}

[1] Ady Soejoto, dkk. Pertumbuhan Ekonomi Dan Pengangguran Terhadap Kemiskinan Di Jawa Timur.
[2] Amalia, Fitri. 2012. The influence of education, unemployment and inflation on poverty rate in eastern indonesia (ITC) 2001-2010.

[3] Arsyad, Lincolin. 2010. Economic development. Yogyakarta: UPP STI M YKPN.

[4] Badan Pusat Statistik. (2016). Sumatera Utara dalam angka 2001-2016. Sumatera utara: Badan Pusat Statistik Provinsi Sumatera Utara.

[5] Idris, and Ramel Yanuarta. 2007. Bahan Ajar :Ekonomi Sumber Daya Manusia. FE UNP.

[6] Perry GE, Arias OS, Lopez JH, Maloney WF, Serven L. 2006. Poverty Reduction and Growth : Virtuous and Vicious Circles. New York: World Bank.

[7] Radityo Yudi Wibisono (2015). Analisis Pengaruh Pdrb, Pengangguran Dan Pendidikan Terhadap Kemiskinan Di Jawa Tengah Tahun 2008 2013.

[8] Sukirno, Sadono. 2004. Pengantar Makro Ekonomi. Jakarta : Rajawali Press.

[9] Todaro, Michael. P . 1994. Ekonomi untuk negara berkembang. Edisi ketiga. Jakarta : Bumi Aksara

[10] 2003. Pembangunan Ekonomi Di Dunia Ketiga. Alih Bahasa:Aminuddin dan Drs.Mursid. Jakarta: Ghalia Indonesia.

[11] Todaro, MP dan Stephen C. Smith. 2004. Pembangunan Ekonomi di Dunia Ketiga 1. Edisi ke Delapan, Jakarta: Erlangga.

[12] Yarlina Yacoub (2012). Pengaruh Tingkat Pengangguran Terhadap Tingkat Kemiskinan Kabupaten/Kota Di Provinsi Kalimantan Barat. Jurnal Eksos Volume 82012. 